\title{
Histoire de la sexualité '4' (Les aveux de la chair): Aantekeninge vanuit die Nederlandse Foucault-navorsing
}

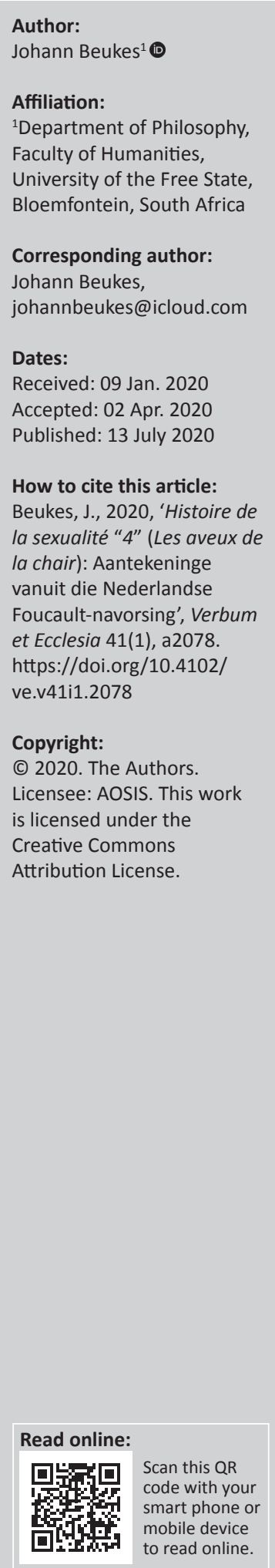

Histoire de la sexualité '4' (Les aveux de la chair): Notes from the Dutch Foucault-scholarship. This article presents an overview of several Dutch disseminations of Michel Foucault's (19261984) Histoire de la sexualité 4 (Les aveux de la chair), since its publication on 8 February 2018 at Gallimard (Paris) under editorship of Frédéric Gros. The exposé positions itself in terms of the most recent (December 2019) outputs of Foucault Cirkel Nederland/België (via the contributions of Steven Dorrestijn, Waldo Heugebaert and Michiel Leezenberg), as well as the recent critical studies of Machiel Karskens and Leezenberg. Several text-critical considerations regarding Les aveux de la chair are presented from these interpretations, in relation to the three standing volumes of Histoire de la sexualité (La volonté de savoir, December 1976, L'usage des plaisirs, May 1984, and Le souci de soi, June 1984). Foucault's exclusion of posthumous publications of his unfinished texts is amplified, since Les aveux de la chair (its sources and time of composition notwithstanding), is indeed a posthumous publication in the strict sense of the word: this aspect is, however, understated in the above receptions, albeit on justifiable grounds (in the sense that the text is regarded to be based fundamentally on Foucault's 1981-1982 Collège de France lectures and was therefore effectively 'published' by June 1984). The recent Dutch reception is in conclusion described as exceptionally erudite and rigorous in its exegesis and reviews of Les aveux de la chair in the span of just two years.

Intradisciplinary and/or interdisciplinary implications: This dissemination of Michel Foucault's Histoire de la sexualité 4 (Les aveux de la chair) impacts various other disciplines, inter alia Studies in Antiquity, Medieval Philosophy, Continental Philosophy, Patrology, Church History and Philosophy of Religion.

Keywords: Daniel Defert; Michel Foucault; Foucault Archives; Bibliothèque Nationale de Paris; Foucault Cirkel Nederland/België; Frédéric Gros; Histoire de la sexualité; Les aveux de la chair; The History of Sexuality.

\section{Histoire de la sexualité 4 (Les aveux de la chair): Inleiding en probleemstelling}

Die uitgelese vakvereniging Foucault Cirkel Nederland/België het op 12 Desember 2019'n colloquium by die Universiteit van Amsterdam gehou om die gevolge van die betreklik onlangse toevoegings tot en wysigings aan die Foucault-argief by die Bibliothèque Nationale de Paris te bespreek. Die toevoegings tot die argief in 2013 (en ten opsigte van die jong Foucault, insluitende sy meestersverhandeling, in 2015') het aanleiding gegee tot ' $n$ hernieude belangstelling in die vroeë Foucault, veral ten opsigte van die beskikbaarstelling van dokumentasie waartoe min of geen toegang tot op datum bestaan het: dit geld onder meer vir Foucault se klaslesings oor seksualiteit in die 1960's, wat aanleiding gegee het tot die publikasie van Deux cours inédits de Michel Foucault sur la sexualité (gepubliseer 2018; sien Leezenberg 2019) en herlesings van Foucault (1961) se ideëhistoriese analises van waansin op grond van die beskikbaarstelling van materiaal wat tot dusver geheel en al onbeskikbaar was of nie geredelik beskikbaar was nie (sien Treiber 2019 en Van Rooden 2019).

1.Sien Massot, Sforzini en Ventresque (2018:2) vir'n oorsig van die ontstaan (vanaf 1994) en mees onlangse toevoegings in 2013 en 2015 tot die Foucault-argief by die Bibliothèque Nationale in Parys. Die skrywers werk tans per projek Foucault Fiches de Lecture (FFL) aan die digitalisering en oop-toegang aanlynstelling van die materiaal (meer as 37000 bladsye in manuskrip) wat sedert 2013 tot die argief gevoeg is. Hierdie massiewe onderneming sluit die transkribering van Foucault se handgeskrewe notas en aantekeninge deur middel van sagteware soos Transkribus in. Soos met Les aveux de la chair, doem die vraag (minstens vir die skrywer) egter op wat die 'status' van sagteware soos Transkribus in. Soos met Les aveux de la chair, doem die vraag (minstens vir die skrywer) egter op wat die 'status' Foucault dit aanvaarbaar kon vind dat persoonlike aantekeninge en notas, oorwegend in sy unieke handskrif en idiosinkratiese snelskrif, op hierdie wyse publiek gestel word sonder dat hy dit self kon redigeer, 'n saak waarop hy altyd aangedring het? Dit is 'n sentrale vraag deur hierdie hele artikel, juis ten opsigte van die beskikbaarstelling van (na die skrywer se mening) ongeoorloofde manuskripmateriaal met die publikasie van Les aveux de la chair. 
Die mees verreikende gevolg van die toevoegings tot die Foucault-argief is egter ongetwyfeld die onlangse publikasie van 'n sogenaamde 'vierde volume' van Foucault se driedelige Histoire de la sexualité (1976, 1984a, 1984b) onder die bekwame redakteurskap van Frédéric Gros (red. 2018), inderdaad getitel Histoire de la sexualité 4 (Les aveux de la chair - 'Die bekentenisse $^{2}$ van die vlees'). Aangesien geen Engelse vertaling van hierdie werk of bovermelde vroeë klaslesings oor seksualiteit nog teen die einde van 2019 gepubliseer is nie, maar die publikasie van 'n Nederlandse vertaling deur Jeanne Holierhoek geskeduleer is vir Januarie 2020 (by Boom Uitgeverij ${ }^{3}$ in Amsterdam; sien Dorrestijn 2020), het Foucault Cirkel by hierdie colloquium 'n bestekopname gedoen oor die winste en probleme wat vanuit hierdie onlangse publikasies na vore getree het, met betekenisvolle bydraes deur die tegniekfilosoof Steven Dorrestijn (2019) van die Saxion Universiteit vir Toegepaste Wetenskap in Deventer, die kultuurfilosoof Waldo Heugebaert (2019) en die eminente Foucault-navorser Michiel Leezenberg (2019), beide van die Universiteit van Amsterdam. Hoewel dit nie by hierdie colloquium as sodanig gedien het nie, moet die uitstaande artikel van Machiel Karskens (2019a) van Radboud Universiteit Nijmegen en Leezenberg se oorsigartikel (2018) as hoogtepunte vanuit die per definisie onlangse Nederlandse resepsie van Les aveux de la chair gevoeg word.

Die oogmerk van hierdie artikel is teen bogenoemde agtergrond om 'n oorsig te verskaf van die mees onlangse Nederlandse disseminasies van Les aveux de la chair, georiënteer aan die werksaamhede van Foucault Cirkel Nederland/België se jongste colloquium, sowel as enkele ander hoogtepunte in die navorsing, met verwysing na Karskens (2019a; sien ook Karskens 2012) en Leezenberg (2018) se bovermelde werke. Die netelige vraag na Foucault se verbod op postume publikasies van sy onvoltooide en selfongeredigeerde manuskripte, gestipuleer kort voor sy afsterwe op 25 Junie 1984, geniet in hierdie artikel deeglike aandag - juis omdat dit een aspek is wat nié sterk aan die bod kom in die Nederlandse resepsie nie (hoewel verantwoord met tekskritiese oorwegings). Daarby sal aangedui word dat Les aveux de la chair nie 'n 'boek' in die gangbare sin van die woord is nie (sien ook Karskens 2019a:559-560): Afgesien daarvan dat die werk grootliks saamgestel is uit Foucault se lesings by die Collège de France vanaf 1977 tot 1982, maar veral vanuit die lesings in die akademiese jaar van 1981 tot 1982 - en die boek dus effektief in daardie twee jaar geskryf is (hoewel 1980 volgens Karskens die waarskynlike jaar van komposisie was) - staan die werk ideë-chronologies voor die tweede en derde volumes van Histoire de la sexualité. In soverre Les aveux de la chair dus wel as 'n addendum tot Histoire de la sexualité in die gedaante van ' $n$ 'vierde volume' geag kan word, is so 'n plasing in elk geval verwarrend. Indien die werk dan staanplek binne die reeks Histoire de la sexualité gegee moet word, sou dit eerder as 'n 'tweede' volume en nie 'n 'vierde' volume nie, moes wees.

2 Alhoewel Afrikaanse begrippe soos belydenis en bieg in di . wees, word ter wille van semantiese korrespondensie by die wees, word ter wille van semantiese bekentenis gehou.

3.ISBN 9789024423941.
Daarby: met inbegrip van die konflikbesaaide kwessie ten opsigte van herwaarderings van Foucault se berugte betrokkenheid by die Iranese revolusie van 1978 tot 1979 (sien Beukes 2020a), is met die publikasie van Les aveux de la chair nogeens 'n kontroversiële tema die bestaande Foucaultnavorsing binnegebring. Die navorsingsgemeenskap is tans verdeel oor die 'status' van die betrokke redaksiewerk, op grond van die basisvraag of Les aveux de la chair juis as 'n 'vierde volume' van Histoire de la sexualité aanvaar behoort te word, omdat 'n hele netwerk van probleme opduik indien instemmend op die vraag gereageer word - en nie juis minder probleme na vore tree indien negatief daarop geantwoord word nie. Die debat oor die legitimiteit van hierdie teks synde 'outentiek Foucault' (of nie) gaan minstens vir die afsienbare toekoms deel vorm van navorsingsmetodologiese gesprekke in die betrokke veld. Die skrywer argumenteer daarom infra dat die navorsing tyd gegun moet word om die teks grondig te dissemineer, voordat dit spontaan as 'n natuurlike addendum tot die bestaande drie volumes van Histoire de la sexualité in die besonder en tot die Foucaultkorpus in die algemeen gevoeg kan word.

In Les aveux de la chair (van hier af $A C)^{4}$ behandel Foucault, binne sy breër aweregs historiografiese ontleding van seksualiteit, die oorgang (of eerder kontinuïteit) vanaf die heidense oudheid na die vroeë Christendom. Hy bespreek die denke en benaderings van kerkvaders soos Klemens van Aleksandrië, Augustinus van Hippo en Johannes Cassianus met betrekking tot seksuele begeerte, die huwelik, vrugverwekking en maagdelikheid, wat hy bed in teologiese kontekste wat handel oor die skepping, voortplanting, sonde (veral met betrekking tot die Augustiniaanse erfsondeleer) en verlossing. Foucault rig hom egter in besonder op die implikasies hiervan vir die lewenspraktyk deur te fokus op temas soos bieg- of bekentenisrituele, pastorale leiding en selfondersoek, soos wat dit aanvanklik in die vroegste kloosterwese en later in die algemene kerk tot uitdrukking gebring is. Foucault dui aan hoe daar gevolglik 'n 'nuwe ervaring' van die innerlike mens ontstaan het, hoe dit in Augustinus se opvattinge van die bewuste wil (geprioritiseerd bo die intellek) neerslag gevind het en hoe die ideaal om die daarin sluimerende seksuele begeerte te onderwerp, ontwikkel het.

\section{Die publikasie van Les aveux de la chair (red. Gros 2018)}

Waarom het hierdie publikasie binne twee jaar na die bekendstelling daarvan, met twee afdelings wat al vir jare in

4. Let op die volgende afkortings:

- Histoire de la sexualité (The history of sexuality) > HS - Nederlands Geschiedenis van de seksualiteit

- Les aveux de la chair (Confessions of the flesh) > AC - Nederlands De bekentenissen van het vlees

- Histoire de la sexualité 1: La volonté de savoir (The history of sexuality, Volume 1 : The will to knowledge) > HS1VS - Nederlands De wil tot weten

- Histoire de la sexualité 2: L'usage des plaisirs (The history of sexuality, Volume 2:

The use of pleasure) > HS2UP - Nederlands Het gebruik van de lusten

- Histoire de la sexualité 3: Le souci de soi (The history of sexuality, Volume 3: The

- Histoire de la sexualite 3: Le souci de soi (The history of sex
care of the Self) > HS3SS - Nederlands De zorg voor zichzelf

- Dits et é écrits $>D E$

- Deux cours inédits de Michel Foucault sur la sexualité > DC

- Collège de France Leçons (lesings met jaartal) > CFL (byvoorbeeld CFL77-78 vir die Collège de France lesings vir die 1977 tot 1978 akademiese jaar) 
Engels beskikbaar is, ${ }^{5}$ reeds tot meningsverskil in onder meer die Nederlandse, Belgiese en Franse navorsing aanleiding gegee? Die antwoord is bedrieglik eenvoudig (en, gegewe die gemaklike wyse waarop dit verbygegaan word, ${ }^{6}$ skynbaar eenvoudig bedrieglik): Foucault het dit naamlik baie duidelik gemaak (so 'on-Foucaultiaans' as wat so 'n poging tot 'n 'soewereiniteit oor sy oeuvre' mag voorkom; Leezenberg 2018:1), selfs nog kort voor sy heengaan op 25 Junie 1984, dat hy enige postume publikasies van sy onvoltooide manuskripte streng verbied, met die bondige woorde: 'Geen postuum publikasies' (Leezenberg 2018:1).

Foucault was onder uitgewers berug vir sy gesteldheid op die selfredigering van sy tekste voor publikasie - maar dit is nie die enigste rede waarom Foucault sodanige verbod op postume publikasies geplaas het nie. Elden (2018:295) dui oortuigend aan dat die reaksie op sy werk vir Foucault juis meer aangrypend was as wat die werk self ooit kon wees, juis omdat hy as 'n 'outeur', ' sover dit hom aangegaan het, hermeneuties 'opgelos' was sodra die werk gepubliseer is. Die feit dat geen debat kon volg op die publikasie van 'n teks of dat hy hom teen kritici kon verweer nie (en die lys van sy meesal gesofistikeerde kritici was altyd lank), was vir Foucault ondenkbaar. Daar bestaan immers vele berigte oor Foucault se bespotting van diegene wat gemeen het dat hulle werk die toets van die tyd sou deurstaan en die een of ander aanspraak op ewigheidswaarde sou hê. Natuurlik sou Foucault ook verras gewees het om te kon waarneem juis hoeveel reaksie sy werke ná 1984 opgeroep het en in watter mate sy teoretiese posisies oor 'n hele spektrum van dissiplines met merkwaardige gelykblywendheid uitgewerk sou word. Maar sou Foucault dit oorweeg het om sodanige gelykblywendheid te waardeer sonder dat hy die geleentheid sou hê om daarop te reageer? Waarskynlik nie.

Foucault het formeel geen testament nagelaat nie, maar in die maande voor sy dood het hy wel 'n nota nagelaat waarin hierdie en ander laaste wense duidelik uitgespel is. Sy woonstel in Parys en die res van sy boedel het hy toevertrou aan sy lewensmaat, Daniel Defert. Daarby het hy gekwalifiseer dat hy onder geen omstandighede kunsmatig

5.Die so vertaalde "The battle for chastity' is reeds beskikbaar gestel in Foucault (1988), terwyl die afdeling 'Maurice Florence' beskikbaar gestel is in die Cambridge Companion to Foucault (red. Gutting 2005), asook in Essential Works II (red. Rabinow 1997)

6.Mark Lambrechts (2019) van Katholieke Universiteit Leuven se aanbevole lys van resensies van Les aveux de la chair (per korrespondensie aan die skrywer verskaf op 25 Desember 2019) is met vrug geraedplo op grond warvan sodanige menis meningsverskil tussen afgeronde lesers van Foucault in Nederland, Belgie en Frankryk duidelik blyk, maar ook aangedui word hoe reikhalsend hierdie werk in spesifiek Nederland in die eere tersaaklike afdelings in Stuart Elden se uitstekende Foucault's last decade (2016) en 'n werklik bruikbare oorsigartikel (2018:293-311), is die onderstaande uiteensetting gebaseer op die inligting vervat, per Lambrecht se resensielys, in Artières (2018:8), Aviet en Poirier (2018:3-4); Boucheron (2018:32-37); Brès (2019:89-91); Cacciar en Lacroix (2018:110); Chevalier (2018a:78-79, 2018b:57-59); Cusset (2018:36); Dautry en Georgesco (2018:2); De Bellefroid (2018:2-3); Devos (2018:387-389); Droit (2018:31); Duru (2018:84-85); Garrigue (2018:32); Grodent (2018:43); Gros en Aviet (2018:5-6); Grunberg (2019:60-65); Jooris en Leyman (2018:5); Kim (2019:92); Lacroix (2018:112-113); Lagouanère (2018:2); Legrand (2018:47-49); Maggiori (2018:26-28); Rahli (2019:900-911); Ratti (2018); Revel en Poirie (2018:7-9); Roudinesco (2018:1); Sabot en Poirier (2018:9-11); Sanders (2018:3841); Schneider (2018:102-103); Sforzini (2019:307-308) en Villeneuve (red. 2018.133-134). Dit is duidelik dat die meerderheid van hierdie besprekings die 2018.133-134). Dit is duidelik dat die meerderheid van hierdie besprekings die vraag na Foucault se verbod op die postume publikasie van sy onvoltooide en selfongeredige manuskipte verbygaan, of hoogstens sydelings daarna verwys. Die navorsing wat dit wél as 'n wesenlike kwessie ag.

7.Vir'n oorsig oor Foucault se problematisering van 'outeurskap', sien Beukes (2020a:1.1). aan die lewe gehou wou word nie. Hy benadruk in dieselfde konteks dat geen werk wat ten tye van sy afsterwe nog (self-) ongeredigeerd of onvoltooid sou wees, postuum gepubliseer mag word nie. Daardie wens - of eerder opdrag - is vir bykans drie dekades deur sowel Defert as Foucault se broer en suster eerbiedig. Defert het trouens so ver gegaan as om Foucault se belangrikste dokumentasie, waaronder derduisende bladsye ongeredigeerde tekste, uit hulle woonstel in Parys te verwyder en vir die volgende bykans drie dekades in 'n bankkluis weg te sluit. Dit is belangrik dat daar vir bykans 30 jaar, vanaf 1984 tot 2013, 'n uitdruklike opset was om Foucault se opdrag te eerbiedig: dit dui daarop dat daar by die belanghebbendes geen twyfel bestaan het oor die gewigtigheid en saaklike inhoud van Foucault se laaste wense nie.

Foucault het wel een uitsondering ten opsigte van postume publikasies gemaak: die publikasie van Dits et écrits 'n dekade ná sy afsterwe het naamlik uitdruklik voorsiening gemaak vir 'n aantal tekste wat hy vir postume publikasie geoormerk het. Hierdie versameling het uiteindelik vier volumes en meer as 3000 bladsye in gepubliseerde formaat bestryk. DE is in hierdie opsig uniek binne die oeuvre: feitlik al Foucault se korter tekste en gepubliseerde onderhoude is deur Gallimard in Frans in hierdie versameling byeengebring, oorspronklik in hierdie vier volumes en later in slegs twee volumes (in die Quartouitgawe). $D E$ het sedertdien ' $n$ onmisbare verwysingsbron in die Foucault-navorsing geword.

In 2013 het Defert egter al Foucault se gebergde manuskripte, notas en aantekeninge aan die Bibliothèque Nationale verkoop, wat die materiaal binne slegs ' $n$ jaar daarna aan die bona fide navorsing beskikbaar gestel het. Toegang tot die dramaties uitgebreide argief is spoedig en aansienlik vergemaklik, sodat die meer as 100 kaste materiaal met meer as 37000 bladsye ongepubliseerde teks, insluitende opsommings en notas in Foucault se buitengewoon moeilike snelskrif, kursusmateriaal, handgeskrewe lesings en 'n groot aantal onvolledige manuskripte, deur die navorsing oopgedek kon word. Dit sluit die tekste in wat uiteindelik in 2018 in die geredigeerde Les aveux de la chair neerslag gevind het.

Bewerings oor ' $\mathrm{n}$ finansiële motief vir die beskikbaarstelling van hierdie materiaal, eers aan die Bibliothèque Nationale en toe aan die navorsingsgemeenskap, moet met omsigtigheid hanteer word. Die kwaliteit van die materiaal as sodanig wat $A C$ se publikasie uiteindelik moontlik gemaak het, kan egter wel as regverdiging dien vir Defert se oënskynlike aanvegbare besluit om die materiaal ná bykans drie dekades vanuit 'n sekuriteitsruimte na die Bibliothèque Nationale te laat oorplaas, om dit onder die redaksieleiding van een van die mees bekwame eietydse Foucault-navorsers in Frankryk, Frédéric Gros, by die prestige uitgewer Gallimard vir publikasie aan te bied. Gallimard was ook verantwoordelik vir die publikasie van die drie staande volumes van Histoire de la sexualité, synde Histoire de la sexualité 1: La volonté de savoir (in Engelse vertaling bekend as The history of sexuality, 
Volume 1: The will to knowledge), Histoire de la sexualité 2: L'usage des plaisirs (The history of sexuality, Volume 2: The use of pleasure), en Histoire de la sexualité 3: Le souci de soi (The history of sexuality, Volume 3: The care of the self), in die uitgewer se gerespekteerde ideëhistoriese reeks, Bibliothèque des Histoires, waartoe $A C$ dus in 2018 gevoeg is. Die vraag is: kan by hierdie drie volumes wat deur Foucault persoonlik geredigeer is, nou (met juis so 'n uitdruklike titel) 'n 'vierde volume' gevoeg word, wat nié deur hom geredigeer is nie en waarvan hy die materiaal wat die publikasie inhoudelik bepaal, uitdruklik van (postume) publikasie uitgesluit het? Kan hierdie 'vierde volume' dus in onproblematiese kontinuïteit met die 'drie outentieke volumes' gelees word?

Dit is waar dat Defert die materiaal verkoop het en pertinent nie kosteloos aan die Bibliothèque Nationale beskikbaar gestel het nie. Nietemin het hy dit nie op veiling geplaas nie: indien Defert 'n kommersiële oogmerk gehad het, kon hy eerder vir die hoogste bod per veiling geskik het - en tog het hy dit juis nie gedoen nie. Defert het ongetwyfeld aansienlike uitgawes gehad om die materiaal vir bykans drie dekades veilig en onder temperatuur- en vogbeheerde omstandighede teen verweer te berg, asook om die materiaal uiteindelik koherent aan die Foucault-argief beskikbaar te stel, sodat die biblioteek die omvangryke versameling binne net ' $n$ jaar daarna kon begin gebruik en effektief kon begin oopstel vir die navorsingsgeselskap. Dit is natuurlik net so waar dat Defert 'n uitdruklike ooreenkoms hiermee verbreek het, naamlik dat hy sy lewensmaat se laaste wense sou eerbiedig en sorg vir sy boedel sou neem, insluitende sy onvoltooide manuskripte, wat uitdruklik nie vir postume publikasie aangebied sou moes word nie. Defert het daardie ooreenkoms vir bykans drie dekades gehuldig en moes 'n uitermate goeie rede gehad het om daardie ooreenkoms uiteindelik te verbreek. Indien geld dan nie die beslissende faktor was nie, wat was? Dit was, om Defert die voordeel van die twyfel te gee, die tekste self, wat inderdaad indrukwekkend is: ook ten opsigte van die vroeë Middeleeue, onder andere vir studente van Foucault wat in Middeleeuse filosofie spesialiseer, soos die skrywer self. ${ }^{8}$ Daarby het die omvang van roofkopieë van Foucault se CFL77-82 (sien infra vir 'n kort oorsig van die vyf jaar se lesings) die afgelope jare sodanige afmetings aangeneem dat die publikasie van 'n kritiese uitgawe van CFL nie langer uitgestel kon word nie (Dorrestijn 2019:1). $A C$ maak onafwendbaar deel uit van daardie publikasiekonteks, aangesien die inhoud van die werk duidelik teruggaan op Foucault se lesings aangebied oor hierdie vyf jaar en 1981-1982 (red. Gros 2001) in die besonder.

Foucault het HS1VS in Desember 1976 gepubliseer, waarin hy hoogs oorspronklike en hiperpolemiese aansprake ten opsigte van die 'konstituerende subjekte van seksualiteit' gemaak het, met verwysing 'die perverse man', 'die

8.Vir voorbeelde van die skrywer se mees onlangse 'Foucaultiaanse' herlesings van Middeleeuse temas en tekste, sien Beukes (2019a, 2020b, 2020d). Let daarop dat Augustinus deur die skrywer as die wesenlike skarnierfiguur tussen die patristiek dat Augustinus deur die skrywer as die wesenlike skarnierfiguur tussen die patristiek en die Middeleeue gedateer word (byvoorbeeld in Beukes 2019b:143 [vn. 3]) en daarom 'as die eerste Middeleeuse filosoof' (Beukes 2020c:1.1) aangebied word. Augustinus hoort na die skrywer se interne periodisering van Middeleeuse filosofie uitdruklik binne die Middeleeuse korpus en daarom hanteer Foucault in $A C$ wél die vroeë Middeleeue (teen die opvatting dat die Middeleeue geheel en al in $A C$ ontbreek; vgl. Dorrestijn [2019:2]) histeriese vrou', 'die masturberende kind' en 'die getroude (Malthusiër) egpaar'. Daar is egter aanduidings dat Foucault se belangstelling reeds gedurende 1976 vanaf die latere Middeleeue in hierdie eerste volume na veel vroeër en trouens antieke materiaal gewend het. Defert herroep byvoorbeeld helder dat Foucault teen Augustus 1977 uitsluitlik met patristiese literatuur besig was (Elden 2018:298-300). Die patristiese element is ook duidelik sigbaar in Foucault se daaropvolgende CFL77-78, vertaal as Security, territory, population, waarin hy hom verdiep het in terme van die Vroeë Christelike pastoraat (Paras 2006:57-90). Hy het dele daarvan ook gebruik vir sy Tanner-lesings Omnes et singulatim by Stanford in die VSA in Oktober 1979. Tydens sy besoek aan Japan in die eerste helfte van 1978 (slegs enkele maande voor hy vanaf September 1978 by die Iranese revolusie betrokke geraak het), het Foucault 'n aanverwante lesing aangebied (vertaal as Sexuality and power) waar hy temas uit die patristiek selfs meer eksplisiet met 'n seksualiteitsanalise verbind het (Beukes 2020a:3), asook die vraag na die verhouding tussen moraliteit en mag behandel het.

Vanaf Januarie 1979 was Foucault voluit besig met 'n eksegese van die tekste van kerkvaders soos Johannes Cassianus, Ambrosius, Augustinus en Tertullianus, wat neerslag gevind het in CFL79-80, vertaal as On the government of the living. In Oktober en November 1980 lewer hy in die Verenigde State by Dartmouth en Berkeley 'n reeks lesings wat nogeens aansluiting vind by die kerkvaders, wat later in Engels gepubliseer sou word as About the beginning of the hermeneutics of the self, opgevolg met sy bydraes by seminare in New York, wat publikasiegestalte gevind het in die vertaalde lesing Sexuality and solitude (Karskens 2019:562-563 [vn. 13]). Met ander woorde, vanaf 1977 tot 1981 was Foucault op die een of ander wyse konstant gemoeid met patristiese literatuur, wat hy in 'n opvolgvolume van HS1VS wou laat neerslag vind. Foucault was nog net nie seker hoe en waar hy dit wou doen nie: hy het in hierdie stadium so 'n magdom oorspronklike materiaal tot sy beskikking gehad dat dit wel duidelik was dat hier sprake sou wees van meerdere volumes in opvolging van HS1VS.

Die manuskrip van $A C$ was naby aan voltooiing in Junie 1984 en Foucault het trouens steeds daaraan gewerk gedurende sy laaste verblyf in die hospitaal, letterlik dae voor sy dood. Die werksdokument is op daardie stadium reeds sonderling betitel as Les aveux de la chair. Hoewel Foucault die manuskrip reeds in Oktober 1982 voorlopig by Gallimard ingedien het, was sy versoek (op grond van 'n aanbeveling van sy vriend, die klassikus Paul Veyne; Leezenberg 2018:2) dat die uitgewer eers met die publikasievoorbereiding van die manuskrip moes wag: sy inleidingshoofstuk in die werk het wel oor antiek heidense seksuele praktyke gehandel, maar Foucault wou sommige van die primêre tekste eers weer lees. Hy het hierdie herlesings breedweg laat dien reeds in CFL80-81, in 'n kursus vertaald getitel Subjectivity and truth, op grond waarvan hy besluit het dat die opvolgvolume vir HS1VS hierdie 
Grieks-Romeinse praktyke sou byeenbring as L'usage des plaisirs. Die veronderstelde derde volume (dit was veronderstel om Les aveux de la chair te wees) van HS sou dan die patristiese materiaal met die heidense materiaal in die tweede volume kontrasteer en integreer. CFL81-82 (in 2001 onder Gros se redakteurskap gepubliseer as L'herméneutique du sujet: Cours au Collège de France) het hierop gevolg en het die wesenlike materiaal via vyf manuskripte verskaf vir wat in 2018 in die redaksiewerk Les aveux de la chair sou uitmond.

Omdat die materiaal vir die beplande tweede volume egter so enorm in omvang was, het Foucault dit in twee verdeel, die eerste deel as L'usage des plaisirs behou en die tweede deel as Le souci de soi betitel (soos hy self in die inleiding van HS2UP [1984a] verduidelik). Le souci de soi sou nou as die derde volume van $H S$ dien. Eers nadat hierdie proses ten opsigte van die skeiding van 'n tweede volume na 'n derde volume afgehandel is, het Foucault die manuskrip teruggetrek wat in Oktober 1982 by Gallimard ingedien is, om dit dus nou as die vierde volume van $H S$ by te werk. Daar was inderdaad, met inbegrip van die aanvanklike voorbehoude wat Foucault oor hierdie manuskrip as 'vierde volume' gehad het en die feit dat die gefinaliseerde tweede (HS2UP) en derde (HS3SS) volumes nou daardie voorbehoude grondig aangespreek het, nie meer soveel afrondingswerk aan die manuskrip vir $A C$ oor nie.

Omdat Franse publikasieskedules in die 1980's oorwegend vinnig was en des te meer so in Foucault se geval, het hy nabye vriende meegedeel dat die 'vierde volume' in Oktober (1984) sou verskyn (Elden 2018:301). HS2UP en HS3SS is inderdaad in Mei en Junie daardie jaar deur Gallimard gepubliseer. Foucault het 'n vaandelkopie van HS3SS in Junie in die hospitaal in ontvangs geneem, slegs dae voor sy dood. Hy was nie in staat om die laaste afrondingwerk aan die vierde volume, $A C$, dus met die oog op publikasie in Oktober, af te handel nie. Die teruggetrekte manuskrip, met Foucault se handgeskrewe korreksies daarop aangebring, asook die voorlopige perskopie vanaf Gallimard, het daarmee op grond van Foucault se uitdruklike opdrag dat nie voortgegaan word met die publikasie van hierdie of enige ander onvoltooide manuskrip wat hy nie persoonlik afgeteken het nie, die sorg van Defert toegeval. Die manuskrip sou die volgende bykans drie dekades in genoemde kluis deurbring.

$A C$ is reeds sedert die tweede kwartaal van 2018 geredelik beskikbaar op verskeie digitale platforms. Hoewel Karskens (2019a) se analise infra gebruik word om die werk kursories inhoudelik te bespreek, kan voorlopig aangedui word dat die werk uit drie hoofafdelings bestaan, met 'n getikte manuskrip wat in 1984240 bladsye beslaan het en die finale gedrukte manuskrip in 2018360 bladsye (Karskens 2019:2 [vn. 6]). In ooreenstemming met die redes vir sy aanvanklike versoek in Oktober 1982 aan Gallimard om die werk nie dadelik persklaar voor te berei nie, is dit duidelik dat Foucault hom vanaf 1980 tot 1984 met forensiese presisie toegespits het op die ideëhistoriese ontwikkeling van antieke heidense na Christelike praktyke en rituele, wat in die eerste van drie dele in $A C$ in die besonder aangespreek word. Twee kritiese 'konstituerende subjekte' vir sowel Vroeë Middeleeuse as patristiese ruimtes word opvolgend in hierdie eerste deel ondersoek in terme van die 'monnik' (of 'om 'n maagd te wees') en die 'getroude man' (of 'om getroud te wees').

Foucault se aanbod is deurtastend en sluit 'n merkwaardige hoeveelheid denkers in, wat wissel vanaf Justinianus in die tweede eeu tot Augustinus en Cassianus in die vyfde eeu, met 'n grondige ontleding van die tersaaklike standpunte van genoemde kerkvadere soos Klemens van Aleksandrië, Gregorius van Nazianzus, Ambrosius, Johannes Chrusostomos, Hieronimus en, in die uitstaande laaste twee hoofstukke van die werk, Augustinus van Hippo. In 'n voubiljet in die dekblad van die eerste oplaag van HS3SS word AC in die vooruitsig gestel as 'n werk wat handel 'oor die vorming van die leerstelling aangaande en die pastoraat van die vlees'; oftewel om die 'nuwe ervaring' aan die (sondig) 'vleeslike' in die eerste eeue van die Christendom te ondersoek en die rol wat die hermeneutiese ontsyfering van seksuele begeerte in hierdie verband speel. Die redaksiewerk Les aveux de la chair doen daardie onderneming wel grootliks gestand.

Gros het as redakteur van Foucault-tekste bekendheid verwerf vir sy keurige byeenbring van Foucault se vyf finale kursusse by die Collège de France (soos bo vermeld, vanaf 1977 tot 1982) en ken hierdie periode in Foucault se loopbaan buitengewoon goed. Hoewel Gros ongetwyfeld die oorwig van die veeleisende opdrag hanteer het, bedank hy in die voorwoord van $A C$ Defert en Foucault se neef Henri-Paul Fruchaud vir hulle 'geduldige en betrokke herlesing van die teks'. Gros was ook deurentyd in kontak en gesprek met twee befaamde Foucault-navorsers in Frankryk, Michel Senellart en Philippe Chevalier. As bronne het Gros sowel Foucault se handgekorrigeerde manuskrip as die getikte perskopie van Gallimard gebruik om die teks op te stel, terwyl hy HS2UP en HS3SS as 'n bloudruk gebruik het om die teks redigeer, met as resultaat 'n stilistiese soortgelykheid tussen die 'vier' volumes - met die eerste volume wat vanweë die diskursiewe en stilistiese eieaardigheid daarvan tog wel van volumes twee tot 'vier' onderskei kan word. Gros het ook nie aan die versoeking toegegee om - anders as wat hy wel oorvloediglik in sy redigerings van Foucault se lesings en kursusse gedoen het - enige iets by te voeg wat nie uitdruklik in Foucault se manuskrip voorgekom het nie. Hy het wel alle numerings en titels van die hoofafdelings, hoofstukke en paragrawe bygevoeg.

Natuurlik laat Foucault se nie-teenwoordigheid by die publiekstelling van hierdie teks 'n enorme leemte. Daarby is die afwesigheid van 'n korrespondensie tussen $A C$ en streng kontemporêre kontinentale belangstellings 'n gegewe - maar hierdie veronderstelde 'agterhaaldheid' van die teks (Karskens 2019a:559) het meer met die nie-teenwoordigheid van die skrywer te doen as met die inhoud van die teks self. Dit is veral waar teen die agtergrond van Foucault se ruim gebruikmaking van gepubliseerde onderhoude, wat in terme van die frekwensie en omvang daarvan vir die 1970's 
buitengewoon was en selfs tot vandag min gelyke het in terme van brute volume. ${ }^{9}$ Ook Foucault se onderhoude rakende sy seksualiteitsanalise in HS1VS kan in die toekoms moontlik problematiese passasies in $A C$ ophelder, wat ook die geval met HS2UP en HS3SS is, aangesien beide gepubliseer is kort voor sy dood en $A C$ in elk geval beide chronologies tematies voorafgaan.

Dit is ook duidelik dat die individue wat betrokke was by die uiteindelik publikasie van $A C$ wel gemoeid was met die kernvraag na Foucault se uitdruklike verbod op postume publikasies. As daardie verbod oortree sou word, moet die kwaliteit van die tekste eenvoudig daarvoor vergoed, afgesien daarvan dat dit teen die hoogste moontlike standaarde geredigeer moes word. Gros het ongetwyfeld in laasgenoemde geslaag. $A C$ is inderdaad nié 'n werk wat deur Foucault voltooi is nie, maar dit is nietemin naby daaraan. Vir lesers wat die werk wil waardeer as 'n inleiding tot (eerder as 'n voortsetting van) HS2UP en HS3SS, is hier veel te vind. ' $n$ Mens kan net spekuleer hoe die boek ontvang sou gewees het indien dit, soos wat Foucault beplan het, voor of gedurende Oktober 1984 gepubliseer sou gewees het, met die skrywer teenwoordig om aan gesprekke oor die meriete, moontlikhede en beperkinge daarvan deel te neem.

Dit alles bring ons terug by die vraag wat inleidend gestel is: behoort $A C$ inderdaad as ' $n$ 'vierde volume' van HS aanvaar te word, en wat ook al die antwoord daarop, is die meningsverskil in die navorsing hieroor geregverdig? Die gebrek aan konsensus oor die status van die werk is na die skrywer se oortuiging (en versetlikheid hieroor) ongetwyfeld geregverdig: aan die hart daarvan is naamlik ' $n$ sin vir filosofiese integriteit. Diegene wat teen die publikasie van die werk was, was oorwegend daarteen op grond van hulle respek vir Foucault as inderdaad 'n 'subjek', 'n 'normale' mens met inderdaad 'genormaliseerde' juridiese regte en morele aansprake. Diegene ten gunste van die publikasie van die werk weeg oorwegend weer Foucault se laaste uitdruklike wense op teen die volhoubaarheid van sy filosofiese nalatenskap: hulle wil Foucault as filosoof om grondige (dit is teksverwante) redes lewend hou, soveel as wat hy die dood filosofies omhels het. Die Foucault-navorsing is meteens weer by ' $n$ kruispad, soos wat dit was (en steeds is) oor sy betrokkenheid by die Iranese revolusie van 1978 tot 1979 - en soos die geval met 'Iran', gaan geen enkele antwoord die korrekte antwoord wees nie. Maar soos met 'Iran' sal 'n verantwoordbare keuse deur lesers gemaak moet word. Die skrywer neem wel kennis van Raffnsøe (2018:397-398) se opmerking dat die beleidsverandering met betrekking tot postume publikasies, synde toenemend 'minder kategories', 'stadig' en 'gefundeerd' verloop het en op die lang duur 'onvermydelik' was. Dit kan egter nie die

9.Sien byvoorbeeld die uitstaande versameling van onderhoude deur Lotringer (red. 1996), Foucault live, collected interviews, 1961-1984. Die meerderheid van hierdie onderhoude was werklik omvangryk en het allerlei betekenisvolle vrae oor Foucault se werk aan bod gebring, wat nie sonder meer deur sy tekste self opgeroep word nie. Die wyer metodologiese standpunt van Lazreg (2017:4) kan onderskryf word: Foucault se onderhoude verskaf' $n$ geleentheid om in praktiese en alledaagse term te verstaan wat sy 'filosofies-teoretiese benadering dikwels geabstraheerd en versluierd' gehou het en behoort ten spyte van geldige vermanings vanuit die navorsing ten opsigte van moontlike skeeftrekking en vervlakking, die aanvullend waarde van die gepubliseerde onderhoude nie te ondermyn nie. laaste woord wees oor wat die skrywer steeds as 'n buitengewoon sensitiewe kwessie beskou nie, naamlik dat Foucault se uitdruklike verbod op postume publikasies tans effektief teengegaan word.

Die skrywer maak teen die agtergrond van bostaande uiteensetting 'n voorlopige aanbeveling: Dit is duidelik dat twee private (dit is, vir Foucault) oorwegings teen mekaar opgeweeg moet word, te wete die morele en die filosofiese. Omdat Foucault nie 'n geldige testament nagelaat het nie, kan sy laaste wense sekerlik nie as juridies afdwingbaar geag word nie. Maar sou die diskursiewe oogmerk of intensionaliteit van 'n subjek nie juis vir Foucault swaarder moes weeg as die juridiese gedetermineerdheid van 'n bepaalde subjektiwiteit nie? Met ander woorde, gaan die oogmerk van 'n wetgewing, of vanuit die gemene reg - in hierdie geval erfreg - en 'n juridiese maatreël deur 'n wetgewer, sowel as die normaliserende effek van die wetgewing op ' $n$ bepaalde subjek, nie die promulgering van die wet of maatreël juis vooraf nie? Behoort Foucault se 'oogmerk' of laaste wense vanuit sy eie teoretiese raamwerk ten opsigte van 'selfeksaminering' en uiteindelik 'selfregering' dus nie in ieder geval hanteer te word as sou dit juridies 'vasgelê' en 'afdwingbaar' wees nie? Indien dan egter volstaan wil word met slegs 'n morele kwalifikasie sonder juridiese inspraak, moet dit steeds korrek wees dat $A C$ as 'n veronderstelde addendum tot $H S$ as 'n 'nie-outentieke teks' beskou behoort te word, wat hoogstens profytlik is as 'n eksterne verwysingsbron na die Foucault-korpus in die algemeen en die drie staande volumes van HS in die besonder. Maar dan weer, 'wat is 'n skrywer?': indien die filosofiese oorweging swaarder weeg, behoort Foucault se herhaalde nadruk op die 'dood van die outeur' en die 'hermeneutiese oplossing van outeurskap' en daarom 'die afwysing van outoriteit' voorrang te geniet. Dit beteken dat, met gelyke respek aan die morele oorweging, die filosofiese oorweging 'n resepsie en eksegese van $A C$ as 'n 'outentieke, primêre Foucault-teks' toelaat, sonder om noodwendig ontrou aan Foucault te wees, sowel as 'n 'persoon' as 'n filosoof van die eerste orde. Ten einde 'n verantwoordelike brug tussen hierdie twee oorwegings te slaan, beveel die skrywer aan dat (1) die gespesialiseerde navorsing genoegsame tyd verleen word om $A C$ as juis 'n redaksiewerk te dissemineer (waarvan Karskens [2019] se werk 'n uitstekende voorbeeld is), en (2) tot tyd en wyl 'n duidelike meerderheidsopinie of breë konsensus in die navorsing gestalte kry, uit respek vir sowel Foucault as Gros, na die teks verwys word as 'n redaksiewerk van Gros. Dit is 'n voorlopige aanbeveling en stel vertroue in die Foucault-navorsing om die saak nie onbeperk in die lug te laat hang nie, maar om gesaghebbende eksegetiese advies te lewer op grond waarvan dit in die toekoms wel moontlik kan word om na die teks slegs met Foucault as outeur te verwys.

Nog een bykomende opmerkings moet ter verheldering gemaak word: die redigering en publikasie van Foucault se CFL77-80 onder Gros se leiding word deur bekwame eksegete soos Karskens (2019a, 2019b) nie as problematies in terme van Foucault se verbod op postume publikasies beskou nie, 
aangesien Foucault die manuskripte van daardie lesings effektief afgeteken het deur die lesings vanaf 1977 tot 1981 te lewer en daarmee publiek te stel. Die lesings word dus implisiet geag buite die parameters van postume publikasies te val. In soverre $A C$ in ' $n$ beduidende mate die produk is van die volgende jaar se lesings, 1981-1982, kan dit as 'n bykomende oorweging gebruik word om die postume publikasie van die werk, hoewel steeds nie noodwendig as 'n 'vierde volume' van HS nie, te regverdig. Die geldige en inderdaad belangrike redaksiekritiese vraag is egter dan of $A C$ nie eerder uitgegee moes word synde in die verlengstuk van CFL77-81 nie - en dat $A C$ soos daardie lesingtekste dan eerder in die reeks Travaux van Seuil/Gallimard sou moes verskyn, as 'n selfstandige toevoeging tot die drie bestaande volumes in Gallimard se reeks Bibliothèque des Histoires, ${ }^{10}$ met boonop 'n bevooroordeelde hooftitel soos Histoire de la sexualité 4 ?

Dit moet benadruk word dat die publikasie van $A C$ algeheel sonder presedent in die Foucault-navorsing is (met inbegrip van Foucault se vergunning rondom die postume publikasie van bepaalde tekste in $D E$ ). Daarby moet beklemtoon word dat die werk as 'n 'vierde volume' tematies chronologies uit plek is en veel eerder as die 'tweede volume' van $H S$ teregkom. Die skrywer se bostaande aanbeveling kan daarom binne hierdie unieke en probleemgelade resepsiekonteks só bondig saamgevat word: $A C$ behoort nie spontaan te dien as 'n vierde volume van $H S$ nie, aangesien dit 'n redaksiewerk is wat gebaseer is op 'n onvoltooide manuskrip wat Foucault nie persoonlik afgeteken het nie, met inbegrip van sowel sy verbod op postume publikasies van onvoltooide manuskripte as die oorweging dat $A C$ eerder binne die resepsiekonteks van Foucault se CFL gesitueer behoort te word. Totdat groter klaarheid oor die kwessie in die navorsing bereik is, behoort verwysings na die werk na Gros as redakteur gerig te word.

So 'on-Foucaultiaans' as wat dit onder ander omstandighede sou wees, is dit duidelik dat oorwegings rondom 'outentisiteit', 'status' en 'Foucault se wens as outeur' ten opsigte van hierdie teks vir die skrywer onder die unieke omstandighede wesenlik belangrik is. Opvallend is hierdie oorweging rondom $A C$ as 'n postume publikasie nie beduidend aanwesig in die huidige Nederlandse resepsie soos hieronder aangebied nie. In daardie opsig word bogenoemde aanbeveling aanvullend tot die bestaande Nederlandse resepsie in die agtergrond gestel. Met die aanbeveling word ook 'n basis geskep om die indeling en strekking van $A C$ op sterkte van die onlangse Nederlandse navorsing uiteen te sit.

\section{Dekor: Die 'nuwe ervaring' in Les aveux de la chair}

In die tweede en derde volumes van Histoire de la sexualité (HS2UP en HS3SS) ontleed Foucault seksuele aktiwiteit deur te fokus op die probleem van seksuele ekses of oordaad, waar die seksuele handeling (veral ten opsigte van die verlies aan 10.Geldige en gewaardeerde opmerking deur Dorrestijn in korrespondensie aan die skrywer op 22 Desember 2019. selfbeheer tydens orgasmiese konvulsies) binne ' $n$ bepaalde ekonomie van plesier gebed moet word, ten einde die subjek steeds in staat te stel om aan die Hellenistiese ideaal van selfbemeestering te konformeer. In $A C$ weer, word seksuele aktiwiteit geproblematiseer deur te fokus op seksuele begeerte of libido, waar die seksuele handeling nie binne 'n ekonomie van plesier gebed word nie, maar binne 'n ekonomie van waarheid. Aangesien die opheffing van die kwaad of 'verlossing van die bose' in die Vroeë Christelike ervaring gekoppel is aan ware selfkennis (wat die openbaarmaking of veruitwendiging van daardie kennis veronderstel, aangesien die subjek se oordeel nie vertrou kan word nie), moet die subjek sigself aan 'tegnieke van die self' onderwerp (waaronder konfessie en pastorale leiding) ten einde die self te 'ken', sodat die waarheid dat hierdie self inderdaad deur seksuele begeerte besete is, kan manifesteer.

Heugebaert (2019:1) se informatiewe inleidingslesing oor Les aveux de la chair dui teen hierdie agtergrond aan dat waar HS1VS 'n histories partikuliere ervaring van moderne seksualiteit ondersoek het waarin subjektiwiteitsvorme na vore tree in terme waarvan individue hulself as 'subjekte van ervaring' herken (in terme van 'n 'hermeneutiek van begeerte'), die opvolgvolumes in HS gemoeid was met die genealogie van sodanige begerende subjek. In hierdie opvolgvolumes verskil AC van HS2UP en HS3SS in terme van die etiek wat in $A C$ aangebied word: hoe word die soort verhouding wat die individu met sigself behoort te hê gedikteer, op grond waarvan die individu veronderstel is om sigself te konstitueer as ' $n$ morele subjek van sy of haar eie handelinge (met verwysing na onder meer etiese substansie, modi van subjektivering, selfvormerende aktiwiteite en telos of selfverwesenliking)? AC kan gelees word as 'n ontleding van hierdie etiek, wat volgens Foucault dui op 'n 'nuwe ervaring': daar vind naamlik in die eerste twee eeue $A J$ 'n verskuiwing plaas van die selfbeheersende etiek van die heidense oudheid na 'n Christelike etiek van verlossing. Die opvatting van die 'sondige vlees' speel in hierdie verskuiwing 'n deurslaggewende rol, synde iets wat ontdek of herken moet word (om die self of eie subjektiwiteit daarin te vind), wat weer 'n bepaalde waarheid aangaande die self tot uitdrukking bring en uiteindelik as 'n boosheid wat oorwin of onderwerp moet word, aanvaar word. Foucault werk in AC gevolglik met twee tekhnès of 'tegnieke van die self', naamlik 'om 'n maagd te wees' en 'om getroud te wees'.

'Om 'n maagd te wees' dui op 'n konstruktiewe verstaan van maagdelikheid as 'n positiewe modus van subjektivering, waarin ' $n$ verhouding met die self tot uitdrukking gebring word waarin die individu sigself herken as 'n gevalle wese wat chronies blootgestel staan voor seksuele begeerte, synde dít wat van buite die wil gewil word op sterkte van seksuele versoekinge. Sodanige seksuele begeerte kan in terme van die 'nuwe ervaring' nie (soos in die heidense oudheid gepostuleer) beheer of bemeester word nie: 'maagdelikheid' dui daarom op die konstante geestelike worsteling met hierdie versoekinge, synde seksuele suggesties en erotiese insinuasies, uitwendig tot die 
individuele wil. Van fundamentele belang in hierdie maagdelike onderneming is nie net konstante selfondersoek nie, maar ook die oopstelling van die self vir pastorale ondersoek na die steeds sluimerende spore van hierdie begeerte en versoekinge in die binnewerkinge van die siel; met ander woorde, 'n openbaarmaking van gedagtes oor seks binne 'n konfessionele konteks (Heugebaert 2019:2).

'Om getroud te wees' dui op die problematiek van die blootgesteldheid aan seksuele begeerte binne die huwelik. Volgens die 'nuwe ervaring' beskik seks oor'n onafwendbare 'bose' element: seksuele begeerte of libido is 'n onwillekeurige reaksie wat onafwendbaar lei tot die seksuele handeling (vergestalt deur ereksie) en kan binne die huwelik nie minder problematies geag word as daarbuite nie (soos benadruk deur Augustinus, wat in die laaste twee hoofstukke van die werk bespreek word). Belangrik is dat seksuele begeerte volgens Foucault in die patristiek nie geag is 'n 'liggaamlike' reaksie te wees wat die siel disoriënteer nie, maar juis die voorwaarde van die siel se onafhanklike vermoë tot wil. Waar seks sonder seksuele begeerte (ereksie) nie moontlik is nie, is daar nietemin ' $n$ element van 'subjektiewe toestemming' in die sin dat daar 'n weerhouding kan wees wat seksuele begeerte nie sonder meer verder as 'sondig' aanmerk nie (Heugebaert 2019:1-2). Dit beteken dat die sondige kwaliteit al dan nie van 'n bepaalde handeling nie verder deur die handeling as sodanig bepaal word nie, maar die 'vorm van die wil' ter sprake (wat seks met 'n uitdruklike voortplantingsopset byvoorbeeld onderskei van ad hoc seksuele kontak ter wille van welke gratifikasie ook al).

Beide maagdelikheid en die getroude lewe word in $A C$ aangebied as sonderlinge antwoorde op die probleem van seksuele begeerte in die 'nuwe ervaring': eerstens word die mens hiermee as 'n subjek van begeerte blootgelê. Die waarheid van die subjek se subjektiwiteit moet gevolglik gevind word in versluierde begeerte, wat slegs deur openbaarmaking of konfessionele veruitwendiging pastoraal opgelos (of 'verlos') kan word. Tweedens plaas die subjek se 'gebruik' van sy of haar libido, sowel as die 'toestemming' wat aan dieselfde libido verleen word (waarvan weerhouding deel uitmaak), sodanige subjek binne 'n juridiese raamwerk wat bepaal watter gebruike en 'toestemmings' toelaatbaar of minstens duldbaar is. Die subjek van begeerte is daarom ook ineens 'n subjek van die (objektiewe) reg. Teen hierdie agtergrond kan die gespesialiseerde eksegese van $A C$ ondersoek word.

\section{Leitmotif, indeling, diskursiewe strekking en kritiese aantekeninge \\ Leitmotif: waarheidsbekentenis en die subjektivering van die selfondersoekende subjek}

Machiel Karskens (2019a) se lesing, 'Het regime van de bekentenissen: Kritische studie van Histoire de la sexualité 4 - Les aveux de la chair', spreek van buitengewone erudisie en beleë hermeneutiese vermoëns. Die werk bied nie net ten opsigte van die Nederlandse resepsie 'n hoogstaande inleiding en oorsig tot $A C$ nie, maar het as beide 'n tekskritiese en redaksioneel kritiese aanbod in die internasionale navorsing weinig gelyke. Dit is van meet af aan duidelik dat Karskens (2019a:559) skepties is oor die bevooroordeelde aanspraak dat $A C$ 'n 'vierde volume' van $H S$ verteenwoordig of selfs 'hoegenaamd 'n boek is': 'Die as vierde en laaste deel van Michel Foucault se Geschiedenis van de seksualiteit aangebode Les aveux de la chair doen nie wat die titels suggereer nie. Die hooftitel suggereer dat die boek die vierde deel van die Geschiedenis van de seksualiteit sou moes wees, maar die teks bestaan uit manuskripte wat nie voortbou op nie, maar tematies voorafgaande tot die tweede en derde deel van die reeks staan. Die tweede titel weer, suggereer dat dit gaan om "die bekentenisse van die vlees", maar die boek ontleed eintlik bekentenisse as 'n onderdeel van die interne reëls van Vroeë Christelike kloostergemeenskappe' (Karskens 2019a:559; cf. 563, 581). Karskens argumenteer opvolgend dat dit nie die 'vlees' as sodanig is wat ter sprake kom in AC nie, maar die seksuele handeling en wellus, in die vergeestelikte vorm van wellustige, sondige eie wil en die 'begerende subjek'. In hierdie sin handel $A C$ diskursief oor Vroeë Christelike waarheids- en lewenspraktyke wat die lewensroetinering of regime van bestaande heidense praktyke nagevolg het en hierdie praktyke na die Christelike ervaring van sowel die (veral Augustiniaanse) erfsonde as die verlossing in 'n lewe 'saam met Christus' oorgedra het.

Hierdie praktykoordrag na die Vroeë Christelike ervaring berus volgens Karskens op 'n enkele en gevestigde Foucaultmotief reeds per HS1VS, naamlik dat 'n mens die 'waarheid moet beken' ten einde deur die waarheidsbekentenis getransformeer te kan word. Die waarheidsbekentenis is selftransformerend in die sin dat dit gerig is op 'n affirmering van die self deur die belydenis of bekentenis van geloof, die openbare skuldbekentenis en uitdruklike blykgewing van skuld, wat byeengebring word onder die begrippe bekentenisse, selfondersoek en geestelike worsteling, onder die begeleiding van 'n pastorale figuur. Aan die hart van hierdie selfbevestiging deur bekentenis lê dialekties selfaflegging of selfopoffering. Karskens (2019a:563-580) argumenteer dat sodanige bekentenisse, selfondersoeke en geestelike worstelings 'n voortsetting is van parresia, die antieke kuns tot selftransformasie deur die waarheid (ongeag gevolge) openlik te praat. ${ }^{11}$ Foucault dui op daardie spoor aan dat seksuele praktyke deur sodanige bekentenisse 'gesubjektiveer' is, bedoelende dat seks as 'n relasionele aangeleentheid gewysig is tot 'n selfgerigte ondersoek na die eie of subjektiewe libidinale begeerte of wellus. Die selfeksaminering ten opsigte van wellus subjektiveer die selfondersoekende subjek ineens as 'n regsubjek, onderhewig aan die een of ander wet. Karskens se bedoeling is om hierdie subjektivering, of vormering van die self, van die selfondersoekende subjek aan

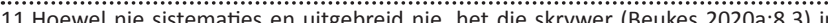
aansluiting by Ghamari-Tabrizi (2016:190-192), geargumenteer dat parresia as ' $n$ aansluiting by Ghamari-Tabrizi (2016:190-192), geargumenteer dat parresia as ' $n$ 'skakel tussen spiritualiteit en etiek' "n betekenisvolle rol gespeel het in die inderdaad uitdagende trant van Foucault se Iran-geskrifte, geskryf in Oktober en November 1978, in dieselfde jaar toe dit prominent in CFL begin figureer het. 
te dui as in die verlengstuk van die selftransformerende parresia-praktyke van waarheidspreke, of skerper gestel, waarheidsbekentenisse, in nie-Christelike antieke kontekste.

\section{Indeling}

$A C$ (sien Figuur 1) bestryk drie dele en vier onbenaamde ekskurse, wat almal voor HS2UP en HS3SS geskryf is, ${ }^{12}$ en gebaseer is op vyf manuskripte wat tussen 1980 en 1982 geboekstaaf is, waarskynlik reeds in 1980 (Karskens 2019a:560-561): Deel I, bestaande uit vier hoofstukke, stel die maatreëls en roetines binne Vroeë Christelike kloostergemeenskappe en gesinne met betrekking tot die aphrodisia (huweliksaangeleenthede in die breë, waaronder seksuele aktiwiteit met prokreatiewe opset en die afwysing van seksuele plesier $)^{13}$ bekend, opgevolg deur drie hoofstukke wat handel oor die uiteenlopende vorme van bekentenisse in die vroeë Christendom; Deel II handel oor die 'maagdelike lewe', wat insluit die kuns van saamleef, selfondersoek en die verwerwing van selfkennis deur die selibaat as 'n positiewe gestalte van seksuele onthouding; terwyl Deel III op die 'getroude lewe' fokus, met betrekking tot die maatreëls en roetinering van die huwelik: slegs die derde en laaste hoofstuk van hierdie deel (en dus die laaste hoofstuk van die werk self) handel inderdaad oor die 'vlees' en hoe spesifiek Augustinus die orgasmiese belewenis met 'n medeganger laat opgaan in die libidinale begeerte van 'n afsonderlike 'wellustige subjek' (waar die relasionele seksuele gebeure dus verplaas word na die enkel oorwegend selfondersoekende en uiteindelik bekentenisdraende of belydende subjek).

Die vier ekskurse hanteer (1) die betreklik gelykmatige korpus van voorskrifte rondom bekentenis in die Griekse en Romeinse literatuur; (2) die feitlik onveranderde oorname van daardie korpus deur die patristiek in die eerste twee eeue $A J$; (3) die wysiging van daardie aanvanklik onveranderde korpus in die herdefiniëring van die verhouding tussen subjektiwiteit en waarheid in die latere patristiek, veral ten opsigte van die verstaan van seksuele plesier en die soort ekonomieë wat daaruit voortkom; en (4) dat hierdie herdefiniëring van die verhouding tussen subjektiwiteit en waarheid nie soseer op 'n verbod aankom nie, maar eerder op 'n ontleding van die parameters van die aphrodisia en hoe subjekte hulle tot daardie parameters moes verbind. Dit is 'dus nie soseer die wet en die inhoud daarvan wat verander het nie, maar die ervaring as voorwaarde tot (self)kennis' (Foucault in red. Gros 2018:365; per Karskens 2019a:561).

12.Juis omdat $A C$ in 'n beduidende mate gelees kan word as die produk van CFL 77-80 behoort ook Foucault se vroeëre lesings (dus voor 1976) ten opsigte van seksualiteit in die resepsie van $A C$ tereg te kom. Die publikasie van Deux cours inédits de Miche Foucault sur la sexualité (in 2018; sien Leezenberg 2019; verkort DC) lewer 'n sonderlinge bydrae om lesings van Foucault gedurende die 1960's as vooruitskouings aan te bied op dit wat uiteindelik sou uitmond in die publikasie van die drie volumes van HS in 1976 en 1984 en AC in 2018.

13.Karskens (2019a:560 [vn.7]) wys daarop dat aphrodisia op soortgelyke wyse in HS2UP en HS3SS beskryf word, maar dat die afwysing van seksuele plesier in $A C$ in
hierdie twee (latere) werke met ' $n$ morele problematisering van plesier vervang word, wat insluit erotiese en homoërotiese spel en 'n positiewe aanduiding van die selibaat (wat in die tweede deel van $A C$ op oorspronklike wyse deur Foucault in verband gebring word met die 'maagdelike lewe' as 'n morele stelsel van 'positiewe onthouding').

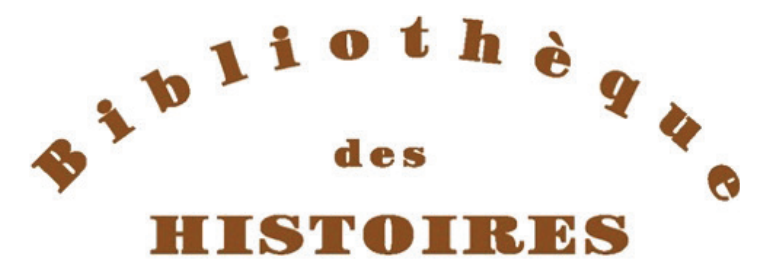

\author{
Histoire \\ de la sexualité
}

4

\section{Les aveux de la chair}

par

MICHEL FOUCAULT

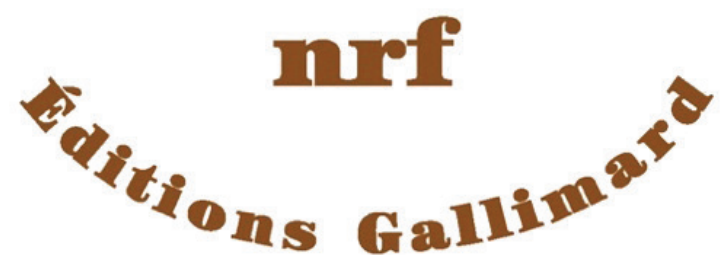

Bron: Gros, F. (red.), 2018, Michel Foucault, Histoire de la sexualité 4: Les aveux de la chair Gallimard, Parys

FIGUUR 1: Voorblad van Michel Foucault se Histoire de la sexualité 4, Les aveux de la chair.

\section{Diskursiewe strekking}

Foucault se aanval in HS1VS op die sogenaamde repressiehipotese, wat in die 1960's buitengewoon gewild in psigoanalitiese en Marxistiese kringe was, het hierdie eerste volume van $H S$ ook van die mees basiese diskursiewe inhoud daarvan voorsien (Leezenberg 2018:2). Volgens hierdie hipotese is die Victoriaanse samelewing gekenmerk deur die onderdrukking van seksuele drifte, wat tot allerlei neuroses aanleiding gegee het en eers gedurende die kultuurrevolusie van die 1960's onder leiding van psigoanalitiese praktisyne soos Wilhelm Reich remedies aangespreek sou word, om daarmee 'n sin of vir selfbegrip van 'seksuele bevryding' te bewerkstellig. Foucault het op nou beroemde wyse geargumenteer dat hier geen sprake was van 'bevryding' nie, maar juis 'n nuwe vorm van magsuitoefening waarin mense opnuut gedwing is om 'die waarheid te beken' en wat geensins verskil van die soort patologisering van seksualiteit (byvoorbeeld 'homo' teenoor 'hetero') wat so dominant in die 
laaste helfte van die 19de eeu was nie (op grond waarvan 'homoseksualiteit' byvoorbeeld vanaf 1891 as 'n diagnoseerbare en geneesbare 'siekte' verstaan is; Beukes 2020d:2). Foucault argumenteer dat seksuele drifte nie 'biologiese' werklikhede is nie, maar vormprodukte van die verhouding tussen kennis en mag. In hierdie sin sit psigoanalise op diskursiewe wyse die Christelike sakrament van die bieg, gekanoniseerd sedert die 12de eeu, bloot voort. Moderne psigoterapeute, net soos die Middeleeuse biegvaders, oefen daarmee 'pastorale mag' oor die individu uit, ter wille van die gewaande liggaamlike en geestelike welsyn van die individu (Leezenberg 2018:2). 'n Gevolglike argument in HS1VS is dat die Westerse samelewing reeds vanaf die 12 de eeu (en nie eers vanaf die Victoriaanse periode nie) sistematies dog repressief op seks gefikseer het: die sosiale konvensies vanuit daardie Middeleeuse periode, wat seksuele kontak streng gereguleer het, het deur middel van die bieg 'n progressiewe openbaarmaking of 'diskoers' geproduseer, wat daartoe gelei het dat hierdie diskoers sedertdien 'n sosiale alomteenwoordigheid geword het. Die begrip seksualiteit is uiteraard self 'n gevolg van die 19de-eeuse diskoers 'seksualiteit' en dit is die rede waarom 'seksualiteit' volgens Foucault 'n betreklik 'onlangse uitvinding' is. Die streng regulering van (en effektief die verbod op enige buitehuwelikse) seks in die Middeleeue was, afgesien dat daarmee 'n selfperpetuerende diskoers tot stand gebring is wat andersins nooit 'n selfstandige diskoers sou word nie, ironies uitermate produktief: seksuele identiteite is daardeur geskep en 'n meervoudigheid van seksualiteite is bevorder (Beukes 2020d:2).

Foucault speur dan in HS1VS die openbare ruimte waarin 'seksualiteit' 'diskoers' sou word, terug na hierdie kerklike praktyk wat reeds in die 12de eeu gestandaardiseerd en verpligtend vir alle kerklike subjekte was, naamlik die bieg juis as ' $n$ vorm van bekentenis: eenmaal in die ope gebring, selfs in die veronderstelde begrensde en sakramenteel vertroulike sfeer van die bieghokkie, sou seksuele voorkeure en oriëntasies nooit weer privaat kon wees nie. In hierdie sin is daar volgens Foucault histories (post-Romeins) wesenlik twee Westerse perspektiewe op seksualiteit aan te merk: die eerste, ars erotica, verskuif die blik geografies vanaf Wes na Oos, na China, Japan, Indië en histories na Athene en Rome, waar ars erotica geassosieer is met 'n geheimenisvolle, privatistiese en erotiese kuns, opgeneem in eksessiewe ervarings wat nie op skande of skuld gedui het nie en dus geen verbod behoef het nie, mits dit in radikale privaatheid beoefen is (met die premisse dat enige vorm van publiekstelling die veronderstelde plesier wat in hierdie verskuilde erotiese ondernemings opgesluit is, sou vernietig). Die ander Westerse perspektief na Foucault se ontleding dui op seksualiteit as die algaande verwetenskapliking van seksualiteit, 'n 'kennis van seksualiteit' of scientia sexualis, waarvan die oorsprong inderdaad die konfessionele praktyk van die Middeleeuse Latynse Weste in die 11de eeu was: presies die teenoorgestelde van ars erotica, is dit nie net die dinamika van die bekentenishandeling - om te praat oor seks, om ondervra te word oor seks nie - maar die voortgaande behoefte in die samelewing sélf om aanhoudend daaroor te bly praat, aangesien die 'waarheid aangaande seks' nou immers reeds in die ope gebring is. Die bieg, synde 'n vorm van bekentenis, speel so 'n sentrale rol as 'n 'individualiseringsprosedure deur mag' (Foucault 1976:92; Karskens 2019a:577).

$A C$, as effektief die 'tweede volume' van $H S$ in ideëchronologiese sin, kan gelees word as ' $\mathrm{n}$ 'stapsgewyse betoog om hierdie sentrale (in HS1VS - JB) hipotese te bevestig' (Karskens 2019a:577). In die 'geestelike worsteling' van die subjek staan sowel die selibaat as die seksdaad voorop in die bekentenis van die eie wellus, begelei (en diskreet afgedwing) deur 'n pastorale leidingsfiguur. Die 'individualiserings prosedures deur mag' in HS1VS is na Karskens se lesing opnuut aanwesig in $A C$, in tweedelige sin: eerstens, die afgedwonge bekentenis en selfondersoek voltrek in die vorm van ' $n$ 'subjektivering' of ' $n$ 'subjektiviteits-waarheidsregime', waarin die 'skuldige' sigself vorm en onderwerp as 'n individueel unieke subjek, iemand met 'n 'eie siel'; tweedens, juis omdat die bekentenis in die teenwoordigheid en onder die streng leiding van 'n ander subjek, naamlik die pastorale leidingsfiguur, uitgespreek word (Karskens 2019a:577). Na hierdie perspektief bevestig en kontinueer $A C$ die dinamika van die bekentenishandeling soos aangetref in HS1VS, naamlik dat dit voortkom uit 'n verpligting tot spreke oor die self, om almal te dwing om daaroor (seks) te praat.

Reeds in CFL75 (19 Februarie 1975; Karskens 2019a:577 [vn. 70]) ondersoek Foucault die Bybelse of minstens Christelike onderskeid tussen enersyds die liggaam (corps) en liggaamlike genietinge (plaisirs) en andersyds die (sondige) 'vlees' (chair) en 'vleeslike begeertes' of wellus (désirs), aan die hand van 17de-eeuse biegtekste. Reeds daar argumenteer Foucault presies die punt waarmee $A C$ eindig - dat dit nie soseer gaan om die sondige wellustigheid in die seksuele gemeenskap met ander subjekte nie, maar juis om die verwoording (en publiekstelling) van die eie seksuele begeertes en intieme gedagtes. ${ }^{14}$ HS1VS van 1976 plaas liggaam en vlees gevolglik in disjunktiewe opposisie. Hierdie opposisie word verleng in die teenoorstelling van ars erotica en scientia sexualis as 'kultureel', naamlik tussen nie-Westerse kulture (soos vermeld, Rome daarby inbegrepe) en die moderne, Westerse Christelike kultuur. Hierdie kulturele teenoorstelling word deur Foucault in HS1VS programmaties uitgewerk, met die onderneming (1976:208) dat 'n opvolgwerk ' $n$ 'teenaanval op die seksualiteitsdispositief' sal behels wat nie sal 'steun op seks en begeerte (chair en désirs) nie, maar op die liggaam en die liggaamlike genietinge' (corps en plaisirs).

Tog word hierdie onderneming nie gestand gedoen nie; presies die teendeel. Wanneer HS2UP agt jaar later verskyn, is dit reeds in die inleidingshoofstuk duidelik dat hierdie opposisie weggeval het - en reeds in die (tematies voorafgaande tot HS2UP) AC word geen breuk met die heidense oudheid en 'n onderdrukking van 'heidense plesier' verder veronderstel nie. Eerder word 'n transformerende kontinuiteit tussen die heidense oudheid en die vroeë

14.'Die "vlees" moet verstaan word as'n ervaringsmodus, bedoelende as 'n modus van kennis en die transformasie van die self deur die self, as ' $n$ funksie van ' $n$
bepaalde verhouding tussen die eliminering van die kwaad en die manifestasie van bepaalde verhouding tussen die eliminering van die kwaad en die manifestasie van
waarheid' (Foucault in Gros [red. 2018:50-51]; per aksent Heugebaert 2019:3). 
Christendom in $A C$ beklemtoon. HS2UP se sentrale tese was, weliswaar geïnformeer deur $A C$, dat die Grieks-Romeinse seksuele praktyke nie aan libidinale drifte georiënteer was nie, maar aan genietinge of plesier: geen voorskrifte of taboes het ten opsigte van seksuele handelinge gegeld nie, maar slegs basiese beginsels tot selfbeheersing, om deur ook die seksuele handeling tot ' $n$ vrye individu of 'n outonome subjek gevorm te word. Natuurlik is Foucault op hierdie punt hewig gekritiseer: sy kultuurhistoriese oriëntasiepunt was die vrye manlike burgers van Athene, terwyl vrouens en slawe se ervaring anders was of kon wees (Leezenberg 2018:3). Tog was die wins van HS2UP se tese die ondermyning van die opvatting dat die Joods-Christelike tradisie die uitsluitlike bron van die Westerse seksuele moraal was: Foucault se aksent op die kontinuïteit tussen die heidense oudheid en die vroeë Christendom in HS2UP is egter ontleen aan die sentrale rol van die monogame huwelik en die 'afwysing' van selfdegeslag seksuele kontak wat hy reeds in $A C$ uitgewerk het.

Met hierdie kontinuïteit bied $A C$ 'n anargeologie of genealogie van die subjek (Karskens 2019a:563), die seksuele lewe en die soort waarheidspreke wat van oudsher af by die seksuele lewensvoering betrokke was, aan. Daarom speel 'n verdere onderskeid tussen die liggaam, liggaamlike genietinge, die sondige vlees en seksuele gratifikasie in $A C$ geen verdere rol nie (Karskens 2019a:578). Die strekking in HS2UP en HS3SS ten opsigte van die problematisering van die seksuele lewe, die lewenskunste, die hermeneutiek van die subjek en die waarheidspel wat by dit alles betrokke is, is effektief deur $A C$ geïnformeer: reeds in die eerste sinne van die teks word die 'diskwalifikasie van plesier' genoem as deel van die oordenking van die seksuele bestaan waarmee die nieChristelike denkers besig was. Hierdie 'diskwalifikasie' het regstreeks toegang gevind in die Christelike vorm van sodanige waarheidspel, naamlik die 'regime van bekentenisse' (Karskens 2019a:578). Maar waar die eerste twee afdelings van HS2UP die liggaam wel nog in behandeling geneem, ontbreek sowel die liggaam as die vlees grootliks in $A C$, selfs nog in die derde en laaste deel oor die huwelik (waar dit immers te wagte sou wees): dit is slegs in die heel laaste hoofstuk waarin seksuele plesier en begeerte, as 'wellus vanuit die erfsonde', 'n rol speel. ${ }^{15}$ Ook daar gaan dit egter nie om die liggaam of die vlees nie, maar om die wellus as 'n (Augustiniaanse) 'katalisator in die geestelike worsteling' op grond waarvan 'die kuisheidsoekende subjek omvorm word tot 'n subjek van begeerte' (Karskens 2019a:578). In kort: wesenlik gaan $A C$ nie oor seks of die vlees nie, maar oor wat 'seksualiteit' en 'spreke oor vleeslikheid' aan mense se selfbegrip doen. ${ }^{16}$

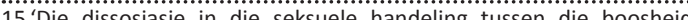
begeerte en die moontlikheid om dit reg of verkeerd die boosheid van seksuele . kodifisering van seksuele gedrag ten opsigte van die gebruike en oogmerke daarvan, die omstandighede wat dit wysig, en so meer. Die twee gebruike wat as legitiem geag is - prokreasie en om die medeganger te verhoed om te sondig word gebruik om die stappe aan te toon waarin seksuele kontak tussen eggenote veronderstel was om te volg, wat toegelaat en wat verbode is, onder watter voorwaardes en ten opsigte van welke gebeure' (Foucault in Gros [red. 2018:359]; per aksent Heugebaert 2019:5)

16.'Dit beteken dat die totale regulering van seksuele gedrag kon van hier af voortgesit word op die basis van die verhouding wat elkeen met homself of haarself moet hê. Die problematisering van seksuele gedrag - of dit verstaan word vir wat dit is en wat dit behoort te wees - word nou die probleem van die subjek' (Foucault in Gros [red. 2018:360]; per aksent Heugebaert 2019:5).

\section{Kritiese aantekeninge}

$A C$ dui dus 'n drastiese verandering vanaf HS1VS na HS2UP aan: dit verskaf 'n ideëhistoriese oorsig van seksuele etiek vanaf die heidense oudheid na moderniteit, maar beweeg ineens anderkant seksualiteit deur'n genealogie van sodanige etiek aan te bied wat as 'subjektiverend' bestempel kan word. Foucault se beskrywing van die ontwikkeling vanaf die Hellenistiese aphrodisia na die Christelike opvatting van die 'sondige vlees' word ondervang deur vars materiaal oor konfessionele praktyke in die vroeë Christendom, die 'maagdelike lewe' en 'n lesing van Augustinus wat tot dusver in die resepsie aangedui word as die belangrikste deel van die werk (Dorrestijn 2019:1; Deel I oor die bekentenis reflekteer die inhoud van CFL80 en Deel III oor die huwelik is niks meer as 'n bywerking van CFL81 nie - slegs Deel II, oor die 'maagdelike lewe' en die lesing van Augustinus in die laaste twee hoofstukke verskaf daadwerklik vars materiaal; sien Karskens 2019a:562). In AC word wel aandag geskenk aan die seksuele begeerte as kontra-wil binne die wil (met inbegrip van die Augustiniaanse prioritisering van die wil bo die intellek), met die subjek se verset teen die kontra-wil as nie gerig teen seks as ' $n$ uitwendige boosheid nie, maar ter wille daarvan om in die reine te kom met 'n 'inwendige onreinheid' - met betrekking tot die erfsondeleer. Die 'maagdelike lewe' word in terme hiervan nie aangebied as ' $n$ vorm van negatiewe onthouding nie, maar as 'n selfaffirmerende en positiewe lewenshouding, of 'n 'selfpraktyk met 'n geestelike dimensie' (Dorrestijn 2019:1).

Foucault vertoef in die drie hoofafdelings van $A C$ by 'n tematiese lesing en interpretasie van die primêre tekste uit die aanvangspatristiek (bedoelende die tekste van sommige [latere] gekanoniseerde teoloë vanaf die tweede eeu), terwyl die Bybelse tekste en liturgiese geskrifte weinig aandag geniet. Foucault se teologiese tekortkominge blyk hieruit ongelukkig duidelik. Die afwesigheid van 'n grondige bywerking van sowel Jesus as Paulus se unieke opvattinge van sowel die 'vlees' as 'onreinheid' word in Nederlandse resepsies gereeld as 'n besondere leemte in die werk uitgewys (Dorrestijn 2019:1). Die teks eindig daarby betreklik kortaf, asof onvoltooid, juis omdat die latere oorgange na die Middeleeue nie verken word nie. ${ }^{17}$ 'n Geldige teologiese vraag is ook op watter wyse die verhouding tussen die liggaam en die vlees in die Reformasie hanteer is en watter invloed dit sou kon hê op die korrektheid van Foucault se ontleding (Dorrestijn 2019:3).

Dorrestijn (2019:3-4) lees Foucault se seksualiteitsgeskiedenis duidelik as konstituerend van 'n genealogie van die subjek, oftewel as wesenlik 'n geskiedenis van die prosesse van subjektivering. Hoewel implisiet, tree Foucault se seksualiteitsanalise met eietydse opvattinge en praktyke met betrekking tot die subjek in fenomenologie en psigoanalise in gesprek. Sy interesse in die bekentenisrituele in die vroeë Christelike kerk koppel met sy ouer analise van dissiplinering in die moderniteit, op grond waarvan 'n meer eksplisiete 17. Die vroeë Middeleeue (minstens met verwysing na Boethius en Pseudo-Dionisius,
naas Augustinus) kon as oorgangsdiskoers vanuit die patristiek byvoorbeeld meer lig gewerp het op die verhouding tussen dissiplineringspraktyke en parresia. 
vraag op grond van Dorrestijn se lesing duidelik word, naamlik: koppel die selfondersoek in bekentenisrituele (met die fokus op seksuele begeerte) vorentoe en vanaf inversies in psigoanalise terug na die Middeleeuse bieg?

As tegniekfilosoof plaas Dorrestijn klem op die implikasies van Foucault se kritiese benadering tot die verhouding tussen bekentenis en dissipline vir 'n 'meer algemene fokus op die bestuur van en vormgewing aan onsself en ander' (2019:4). Hoe sou hierdie meer algemene fokus gebruik kan word om magsuitoefening in die eietydse samelewing te ontmasker met betrekking tot die invloed van die gekonfigureerde magsrites van tegnologie? Die wending na selfpraktyke in $A C$ dui vir Dorrestijn op 'n sensitisering vir die invloed van tegniek op mense se selfbegrip, maar ook om 'bewustelik en krities om te gaan met die wyses waarop tegniek aan die subjek vorm gee', met ander woorde, wat die verhouding tussen tegniek en subjektivering is. Is ons egter nog in staat om hierdie 'invloede van die tegniek' te herken? Vir Dorrestijn (2019:3) is dit die wesenlike vraag binne die konteks van die 'verleidinge van aanlyn bemarking en beïnvloeding via sosiale media' en stel dit $A C$ in ons midde as 'n aktuele werk, wat vrae oproep soos 'Hoe moet ons die vrye wil (in die 21ste eeu) verstaan?' en 'Op watter maniere word ons wil deur tegniek afgelei en verlei?'

Leezenberg (2018:4-5; in die eerste grondige oorsigartikel wat ná 08 Februarie 2018 in Nederland verskyn het) se diskoersontleding van $A C$ fokus inderdaad, na Dorrestijn se boverwysde nadruk, op die laaste twee hoofstukke van die werk, dit is, op Augustinus. Geen skrywer was volgens Foucault so belangrik vir die reglementering en juridisering van seks binne die huwelik en vir 'n herdefinisie van die mens as 'n subjek van seksuele begeerte as juis Augustinus nie. Hierdie twee oorwegings - die huwelik en seks - het na Foucault se lesing van Augustinus 'n enorme invloed op die Westerse Christendom uitgeoefen en lê steeds ten grondslag van moderne Westerse opvatting van seksuele identiteit. Foucault se lesing van die patristiek koppel (hoewel implisiet) terug na sy kritiek van psigoanalise in HS1VS: seksuele begeerte word nogeens in $A C$ aangedui as geen natuurlike aandrif nie, maar die produk van 'n spesifieke Christelike geskiedenis en van spesifieke Christelike vorme van magsuitoefening en onderwerping (Leezenberg 2018:4).

Die aardse mens is na Foucault se Augustinus-lesing nie in staat om die fisieke oorweldiging van seksuele begeerte onder beheer te bring nie. Seks kom wel in die paradys voor, maar word daar gekenmerk deur die afwesigheid van wellus en die volledige onderworpenheid van seksuele begeerte aan die wil. Dit is slegs ná die sondeval dat seks 'n sondige karakter verkry, omdat die menslike wil daarna juis deur sodanige begeerte oorheers word. Dit is waarom die man en vrou eers dán skaamte ervaar aan hulle eie en die ander se naaktheid. Die mens kan die stryd teen hierdie begeerte - as 'n verwyser na, maar self ook reeds die helderste manifestasie van die erfsonde - nie op eie krag oorwin nie, maar slegs deur die Goddelike genade. Foucault (in red. Gros 2018:342 ev.) argumenteer egter dat Augustinus se denke reeds 'n kontinuïteit met die heidense oudheid vertoon, in die sin dat die seksuele handeling nie seksuele plesier as sodanig voor oog behoort te hê nie, maar 'n alternatiewe opgaaf van die vormering van die subjek, in die Christendom vertaal as die 'voortplantingsopset'. Augustinus bring volgens Foucault wel 'n belangrike verandering aan, hoewel die opvatting dat die seksuele begeerte aan die wil moet ontsnap, nie nuut was nie. Wat nuut is by Augustinus, is dat hy die seksuele begeerte nie soos by Plato en Aristoteles as 'n laer fakulteit van die siel aanmerk nie, of 'as 'n passie wat die vryheid van die siel inperk' soos by Spinoza nie, maar dat die seksuele begeerte inderdaad 'die vorm van die wil as sodanig is, oftewel dit wat van die siel 'n subjek maak' (Leezenberg 2018:4).

Leezenberg (2018:4-5) dui aan dat die eerste Franse resepsies van $A C$ betoog het dat Foucault Augustinus se rol in die juridisering van binnehuwelikse seks oordryf het en te min aandag geskenk het aan die invloed van die gnostiek op die vroeë Joods-Christelike tradisie. Foucault vermeld inderdaad slegs kursories dat die Vroeë Christelike tegnieke van die getroude lewe sigself onderskei van die gnostiese opvatting dat iedere vorm van seks, juis ook binne die huwelik, afwysbaar is. Foucault speur ook nie die enorme invloed van die rigiede geestelike en materiële dualisme van Manicheïsme op die (hoewel jong) Augustinus na nie. Augustinus se Paulinies gedrewe, dringende, eskatologiese verwagting word ook nie in berekening gebring nie. Hierdie leemtes stempel Dorrestijn se bogenoemde verwysing na die kritiek op die teologiese verskraaldheid van die werk.

\section{Gevolgtrekking: die Nederlandse resepsie van Les aveux de la chair 2018-2019}

Die Nederlandse resepsie van Les aveux de la chair in slegs die twee jaar sedert die publikasie van hierdie redaksiewerk op 8 Februarie 2018 is indrukwekkend: indien die getal oorsigartikels en resensies in die kort periode en juis ook die kwaliteit van hierdie besprekingswerke in ag geneem word (per Lambrechts 2019), asook die diepgang van die gespesialiseerde navorsing soos vergestalt in die kritiese lesings van Karskens (2019a) en Leezenberg (2018), die toegewyde fokus van Foucault Cirkel Nederland/België om hierdie teks en ander resente Foucault-publikasies te aktualiseer, soos verteenwoordig deur die uitsette van Dorrestijn (2019), Heugebaert (2019), Leezenberg (2019), Treiber (2019) en Van Rooden (2019), en die Nederlandse vertaling van die werk (De bekentenissen van het vlees) by Boom Uitgeverij (2020; vir die beoogde Nederlandse simposium oor die vertaalde werk, sien Dorrestijn 2020), is dit duidelik dat die Nederlandse Foucault-navorsing in terme van intensiteit en erudisie in die voorste linies van die internasionale disseminasie van Les aveux de la chair staan.

Gegewe die ideëhistoriese gapings wat steeds deur die staande drie volumes van Histoire de la sexualité en Les aveux de la chair as addendum gelaat word, spesifiek ten opsigte 
van die 6de tot die 11de eeue en die 16de eeu, met minstens twee tersaaklike manuskripte ( $\mathrm{La}$ chair et le corps en $\mathrm{La}$ croisade des enfants) beskikbaar in die Bibliothèque Nationale, is Les aveux de la chair waarskynlik nie die laaste redaksiewerk in die reeks Histoire de la sexualité nie: daar bestaan reeds 'n realistiese verwagting dat 'n vyfde en 'n sesde volume die lig sal sien om hierdie gapings tussen die kerkvaders en die vroeë moderne periode te vul (Raffnsøe 2018:415). Dit sal openbarend wees indien sodanige werke onder meer lig kan werp op die vraag na Foucault se hantering van die Franciskane en Dominikane se voortslepende konflikte in die 13de en 14de eeue oor juis die verhouding tussen die wil en die intellek, met die Franciskane se (Augustiniaanse en, op die lang duur, triomfantelike) diskursiewe prioritisering van die wil bó die intellek, en of hy dit effektief kon bywerk.

Sodanige 'opvolgvolumes' van Histoire de la sexualité sou egter onvermydelik as redaksiewerke moes verskyn en as postume publikasies hanteer moes word, wat uitdruklik en om goeie redes deur Foucault buite perke gestel is. Ook dan sou die gespesialiseerde navorsing vertrou moet word om die 'outentisiteit' en 'statuur' van sodanige redaksiewerke op sterkte van intensiewe eksegese aan te beveel of af te wys. Ook dan behoort nie met onkritiese vooroordeel na sodanige werke verwys te word as Histoire de la sexualité ' 5 ' of ' 6 ' nie, net so min as wat onproblematies na Les aveux de la chair as Histoire de la sexualité ' 4 ' verwys kan word.

\section{Erkenning}

Die skrywer is 'n assosiaat van die Sentrum vir die Geskiedenis van Filosofie en Wetenskap (CHPS), Radboud Universiteit Nijmegen, Nederland.

\section{Mededingende belange}

Die skrywer verklaar dat hy geen finansiële of persoonlike verbintenis het met enige party wat hom nadelig kon beïnvloed in die skryf van hierdie artikel nie.

\section{Outersbydrae}

J.B. is die enigste skrywer van hierdie artikel.

\section{Etiese oorwegings}

Hierdie artikel volg alle etiese standaarde vir navorsing sonder direkte kontak met mens of dier.

\section{Befondsing}

Hierdie artikel is befonds deur die Departement Filosofie, Fakulteit Geesteswetenskappe, Universiteit van die Vrystaat.

\section{Data beskikbaarheidsverklaring}

Datadeling is nie van toepassing op hierdie artikel nie, aangesien daar in hierdie studie geen nuwe data geskep of ontleed is nie.

\section{Vrywaring}

Die sienings en menings wat in hierdie artikel uitgedruk word, is dié van die outeur en weerspieël nie noodwendig die amptelike beleid of posisie van enige geaffilieerde agentskap van die outeur nie.

\section{Bibliografie}

Artières, P. 2018, 'Michel Foucault, Histoire de la sexualité 4: Les aveux de la chair', L'Obs 2779, 80. https://doi.org/10.19053/01235095.v4.n23.2018.8980

Aviet, F. \& Poirier, N., 2018, 'Michel Foucault, Histoire de la sexualité 4: Les aveux de la chair', La Quinzaine Littéraire 1188, 3-4.

Beukes, J., 2019a, “'Foucault se sodomiet”: Damianus se Liber gomorrhianus (1049) heropen', HTS Teologiese Studies/Theological Studies 75, Art. \#5216, 1-13. https://doi.org/10.4102/hts.v75i4.5216

Beukes, J., 2019b, 'De potestate regia et papali: 'n "uurglas"-bywerking van die mees onlangse Quidort-navorsing', Litnet Akademies 16(2), 109-168.

Beukes, J., 2020a, Foucault in Iran, 1978-1979, AOSIS, Kaapstad.

Beukes, J., 2020b, 'Die eliminering van die siel in die filosofiese mistiek van die begyn Marguerite Porete (1250-1310)', Litnet Akademies 17 (In publikasie).

Beukes, J., 2020c, Mddeleeuse filosofie, Volumes I \& II, Akademia, Pretoria.

Beukes, J., 2020d, 'Intervroulike seksualiteit in die latere Middeleeue: ' $n$ ideëhistoriese oorsig, Verbum et Ecclesia 41, Art. \#2074, 1-12. https://doi.org/10.4102/ve. v41i1.2038

Boucheron, P., 2018, 'Michel Foucault, Histoire de la sexualité 4: Les aveux de la chair', L'Histoire 448, 32-37.

Brès, Y., 2019, 'Michel Foucault, Histoire de la sexualité 4: Les aveux de la chair', Revue Philosophique de la France et de l'Etranger 2019(1), 89-91.

Cacciari, M. \& Lacroix, A., 2018, 'Michel Foucault, Histoire de la sexualité 4: Les aveux de la chair', L'Express, 21 Maart, 110.

Chevalier, P., 2018a, 'Michel Foucault, Histoire de la sexualité 4: Les aveux de la chair', Philosophie Magazine Hors-série 36, 78-79.

Chevalier, P., 2018b, 'Michel Foucault, Histoire de la sexualité 4: Les aveux de la chair', Lire 2018(3), 57-59.

Cusset, F., 2018, 'Michel Foucault, Histoire de la sexualité 4: Les aveux de la chair', Beaux Arts 2018(4), 36.

Dautry, M. \& Georgesco, F., 2018, 'Michel Foucault, Histoire de la sexualité 4: Les aveux de la chair', Le Monde des Livres, 9 Februarie, 2.

De Bellefroid, E., 2018, 'Michel Foucault, Histoire de la sexualité 4: Les aveux de la chair', La Libre Belgique-Lire, 12 Maart, 2-3.

Devos, R., 2018, 'Michel Foucault, Histoire de la sexualité 4: Les aveux de la chair', Tijdschrift voor Filosofie 2018(2), 387-389.

Dorrestijn, S., 2019, 'The confessions of the flesh finally published: A project with breaks and loose ends', ongepubliseerde referaat gelewer by die colloquium van Foucault Cirkel Nederland/België, Universiteit van Amsterdam, Amsterdam, 12 Desember, 1-2; Addendum: 'Postume publicatie van Michel Foucaults Bekentenissen van het vlees', 3-4.

Dorrestijn, S., 2020, 'Programma voor Symposium: Foucaults Bekentenissen van het vlees', Titus Brandsma Institute, Foucault Cirkel Nederland/België \& Lectoraat Ethiek \& Technologie (Saxion Hogeschool Deventer), 29 May.

Droit, R-P., 2018, 'Michel Foucault, Histoire de la sexualité 4: Les aveux de la chair', Les Echos Week-end, 2 Februarie, 31.

Duru, M., 2018, 'Michel Foucault, Histoire de la sexualité 4: Les aveux de la chair', Philosophie Magazine 117, 84-85.

Elden, S., 2016, Foucault's last decade, Polity Press, Cambridge.

Elden, S., 2018, 'Review: Michel Foucault, Histoire de la sexualité 4: Les aveux de la chair', Theory, Culture and Society 35(7-8), 293-311. https://doi.org/10.1177/ 0263276418800206

Foucault, M., 1961 (2006 edn.), History of Madness, transl. J. Murphy \& J. Khalfa, Routledge, Londen.

Foucault, M., 1976 (transl. 1978), Histoire de la sexualité 1, La volonté de savoir, Gallimard, Parys (The history of sexuality, Volume 1: The will to knowledge, vert. R. Hurley, Pantheon, New York, NY).

Foucault, M., 1979, 'Dialogue between Michel Foucault and Baqir Parham', transl. J. Afary, in J. Afary \& K. Anderson (eds.), 2005, Foucault and the Iranian revolution Gender and the seductions of Islam, bl. 183-189, University of Chicago Press, Chicago, IL.

Foucault, M., 1984a (transl. 1985), Histoire de la sexualité 2: L'usage des plaisirs, Gallimard, Parys (The history of sexuality, Volume 2: The use of pleasure, transl. R. Hurley, Random House, New York, NY).

Foucault, M., 1984b (transl. 1986), Histoire de la sexualité 3: Le souci de soi, Gallimard, Parys (The history of sexuality, Volume 3: The care of the self, transl. R. Hurley, Pantheon, New York, NY)

Foucault, M. 1988, 'The battle for chastity', in transl. A. Sheridan, L.D. Kritzman (ed.) Michel Foucault: Politics, philosophy, culture: Interviews and other writings, 227-241, Routledge, New York, NY. 
Garrigue, L., 2018, 'Michel Foucault, Histoire de la sexualité 4: Les aveux de la chair', Sciences Humaines 2018(5), 303, 332.

Ghamari-Tabrizi, B., 2016, Foucault in Iran. Islamic Revolution after the Enlightenment, University of Minnesota Press, Minneapolis, MN.

Grodent, M., 2018, 'Michel Foucault, Histoire de la sexualité 4: Les aveux de la chair', Le Soir, 3 Maart, 43.

Gros, F. (ed.), 2001, Michel Foucault, L'herméneutique du sujet: Cours au Collège de France; 1981-1982, Seuil/Gallimard, Parys.

Gros, F. (ed.), 2018, Michel Foucault, Histoire de la sexualité 4: Les aveux de la chair Gallimard, Parys.

Gros, F. \& Aviet, F., 2018, 'Michel Foucault, Histoire de la sexualité 4: Les aveux de la chair', La Quinzaine Littéraire 1188, 5-6.

Grunberg, A., 2019, 'Michel Foucault, Histoire de la sexualité 4: Les aveux de la chair' De Groene Amsterdammer, 21 Februarie, 60-65.

Gutting, G. (ed.) 2005, The Cambridge Companion to Foucault, Cambridge University Press, Cambridge.

Heugebaert, W., 2019, 'Les aveux de la chair (2018): A very short introduction' ongepubliseerde referaat gelewer by die colloquium van Foucault Cirkel Nederland/België, Universiteit van Amsterdam, Amsterdam, 12 Desember, $1-2$

Jooris, A. \& Leyman, D., 2018, 'Michel Foucault, Histoire de la sexualité 4: Les aveux de la chair', De Morgen, 14 Februarie, 5.

Karskens, M., 2012, Michel Foucault, Boom Uitgeverij, Amsterdam (Lannoo, Leuven).

Karskens, M., 2019a, 'Kritische studie. Het regime van de bekentenissen. Foucaults Histoire de la sexualité 4: Les aveux de la chair', Tijdschrift voor Filosofie 81(3), 559-581.

Karskens, M., 2019b, 'Latere toevoegingen' - re Karskens 2019a, e-pos, 26 Desember mkarskens@phil.ru.nl

Kim, C., 2019, 'Michel Foucault, Histoire de la sexualité 4: Les aveux de la chair', Art Press 2019(3), 92. https://doi.org/10.19053/01235095.v4.n23.2018.8980

Lacroix, A., 2018, 'Michel Foucault, Histoire de la sexualité 4: Les aveux de la chair', L'Express, 24 Januarie, 112-113.

Lagouanère, J., 2018, 'Michel Foucault, Histoire de la sexualité 4: Les aveux de la chair', Le Monde des Livres, 9 Februarie, 2.

Lambrechts, M., 2019, 'Recencies Les aveux de la chair', e-pos, 25 Desember lambrechts.mark@gmail.com.

Lazreg, M., 2017, Foucault's orient: The conundrum of cultural difference, from Tunisia to Japan, Berghahn Books, New York, NY.

Leezenberg, M., 2018, 'Foucaults Les aveux de la chair: Een eerste bespreking', 1-5, besigtig 2 Januarie 2020, by https://www.academia.edu/35977814/Foucaults Les aveux de la chair Een eerste bespreking; sien ook 'Foucault, seks en Augustinus', De Nederlandse Boekengids, April-Mei 2018, 6-7.
Leezenberg, M., 2019, 'Foucault's 1960s lectures on sexuality: Deux cours inédits de Michel Foucault sur la sexualité (2018)', ongepubliseerde referaat gelewer by die colloquium van Foucault Cirkel Nederland/België, Universiteit van Amsterdam, colloquium van Foucault Cirk

Legrand, S., 2018, 'Michel Foucault, Histoire de la sexualité 4: Les aveux de la chair', Le Nouveau Magazine Littéraire 2018(2), 47-49.

Lotringer, S. (ed.), 1996, Foucault Live, Michel Foucault Collected Interviews, 19611984, transl. L. Hochroth \& J. Johnston, Semiotext(e), New York, NY.

Maggiori, R., 2018, 'Michel Foucault, Histoire de la sexualité 4: Les aveux de la chair', Libération, 8 Februarie, 26-28.

Massot, M-L, Sforzini, A. \& Ventresque, V., 2018, 'Transcribing Foucault's handwriting with Transkribus', Foucault Fiches de Lecture, 6 November, 1-12, besigtig 28 Desember 2019, by https://hal.archives-ouvertes.fr/hal-01913435v1/document.

Paras, E., 2006, Foucault 2.0: Beyond power and knowledge, Other Press, New York, NY

Rabinow, P. (ed.), 1997, The essential works of Michel Foucault 1954-1984, Volumes I \& II, The New Press, New York, NY.

Raffnsøe, S., 2018, 'Michel Foucault's Confessions of the Flesh. The fourth volume of the History of Sexuality', Foucault Studies 25, 393-421. https://doi.org/10.22439/ fs.v0i25.5593

Rahli, H., 2019, 'Michel Foucault, Histoire de la sexualité 4: Les aveux de la chair', Critique 2019(869), 900-911. https://doi.org/10.3917/criti.869.0900

Ratti, S., 2018, Les aveux de la chair sans masque, Editions universitaires de Dijon, Dijon.

Revel, J. \& Poirier, N., 2018, 'Michel Foucault, Histoire de la sexualité 4: Les aveux de la chair', La Quinzaine Littéraire 1188, 7-9.

Roudinesco, E., 2018, 'Michel Foucault, Histoire de la sexualité 4: Les aveux de la chair', Le Monde des Livres, 9 Februarie, 1.

Sabot, P. \& Poirier, N., 2018, 'Michel Foucault, Histoire de la sexualité 4: Les aveux de la chair', La Quinzaine Littéraire 1188, 9-11.

Sanders, S., 2018, 'Michel Foucault, Histoire de la sexualité 4: Les aveux de la chair', De Groene Amsterdammer, 21 Junie, 38-41.

Schneider, M., 2018, 'Michel Foucault, Histoire de la sexualité 4: Les aveux de la chair', Le Point, 15 Februarie, 102-103.

Sforzini, A., 2019, 'Les aveux de la chair', Encyclopaedia Universalis 2019, 307-308.

Treiber, G., 2019, 'Back to Madness: The return to the early Foucault and future publications', unpublished paper at the colloquium of Foucault Circle Netherlands/ Belgium, Universiteit van Amsterdam, Amsterdam, 12 Desember.

Van Rooden, A., 2019, 'Some remarks on Folie, langage, littérature (2019)', ongepubliseerde referaat gelewer by die colloquium van Foucault Cirke Nederland/België, Universiteit van Amsterdam, Amsterdam, 12 Desember.

Villeneuve, C.D., 2018, 'Michel Foucault, Histoire de la sexualité 4: Les aveux de la chair', Etudes 2018(5), 133-134. 